\title{
Volatility Diagnostics for Stock Price of Sharia- Compliant Companies listed in Malaysia Composite Index
}

\author{
Nashirah Abu Bakar ${ }^{1}$, Sofian Rosbi ${ }^{2}$ \\ ${ }^{1}$ Islamic Business School, College of Business, Universiti Utara Malaysia, Kedah, Malaysia \\ ${ }^{2}$ School of Mechatronic Engineering, Universiti Malaysia Perlis, Malaysia
}

\begin{abstract}
The objective of this study is to evaluate the volatility of sharia-compliant companies that listed on Malaysia Stock Exchange. Data of return for each of the companies are collected from Thomson Reuters Datastream. The number of selected companies is 19 that selected from 30 companies composing Kuala Lumpur Composite Index (KLCI). This study calculated average monthly return and volatility rate for each of the companies. Next, normality statistical test is performed using Shapiro-Wilk normality test. Result indicates the mean value of average monthly return is $0.442 \%$ with standard deviation $1.28 \%$. Then, the mean value for volatility rate is $4.85 \%$ and standard deviation is $2.23 \%$. Result from Shapiro-Wilk normality test indicates data distribution for average monthly return and volatility follow normal data distribution. The significant of these findings is it will help investors to understand the behavior of stock price in Malaysia Stock Exchange particularly sharia-compliant companies in Kuala Lumpur Composite Index. In addition, the findings of this study will help investors to develop investment portfolio that can maximize return and reducing loss.
\end{abstract}

Keywords-Volatility, Sharia-compliant companies, Malaysia Stock Exchange, Kuala Lumpur Composite Index, Islamic Finance.

\section{INTRODUCTION}

There has been an increasing body of literature on shariacomplaint companies' performance worldwide (Abu Bakar and Rosbi, 2018a; Che Azmi, et al., 2016). The main objective of sharia compliant companies is to provide Islamic investment that free from any prohibited elements in Islamic rules. Islamic-based investments are obligated to follow sharia rules, which means that they must not only be free from elements of riba' (interest) and gharar (uncertainty) but also from activities related to maysir (gambling), alcohol, tobacco, drugs or any form of activity that could pose potential harm to the society or nation (Abu Bakar and Rosbi, 2017(a); Che Azmi, et al., 2016; Ullah et al., 2014; Abdul Rahim and Yong, 2010).
Lusyana and Sherif, (2017) explained that Islamic investment principles emphasize ethical investing that comply with the principles of sharia, which is the Islamic law that governs every facet of each Muslim's life. While, Che Azmi et al., (2016) emphasize that investors are not only concerned with environmental, social, governance issues (Hamza, 2013) and ethical issues as a part of their investment decisions but they also must monitor their activities in order to achieve the motivations and objectives of the social responsibility investing.

Bursa Malaysia has authority in select top 30 largest listed companies. The main function in selecting top 30 largest listed company is to enhance trading and appreciation of the Malaysian market. Out of 19 companies from 30 largest companies listed on Bursa Malaysia was sharia compliant company that was composing the Malaysian composite index. This number shows that sharia-compliant companies were attracting not only Muslim investors but also non-Muslim investors who are interested in investing in Islamic investment. Thus, top 30 largest companies must have a good performance in term of operation and financial. However, with the current economic condition in Malaysia is always change, sharia-compliant companies must monitor their performance especially on the volatility of shares prices in order to be positive, stable and maintain listed as the top 30 largest listed companies of Bursa Malaysia. Therefore, forecasting volatility of shares price plays important roles in investment market (Abu Bakar and Rosbi, 2017b).

Stock market is one of the most important indicators on how the economic are moving up. Positive increment of dynamic movement for the share price indicates good performance of stock market in Malaysia (Abu Bakar, et al., 2018b).Thus, this study was evaluating the volatility of sharia-compliant companies that listed on Malaysia Stock Exchange. The number of selected companies is 19 that selected from 30 companies composing Kuala Lumpur Composite Index (KLCI). 


\section{LITERATURE REVIEW}

Companies that are classified under the sharia-compliant category in Malaysia increased rapidly since the inception of this classification in 1999 in the Malaysian market (Ahmed Haji and Mohd Ghazali, 2013; Ousama and Fatima, 2010). As reported by Securities Commission of Malaysia out of 689 companies from 902 companies are sharia compliant companies (Securities Commission of Malaysia, 2018).

Therefore sharia compliant companies are looking as a good platform in promoting Islamic capital market. Study by Wan Ismail, et al., (2015) regarding quality of earnings in sharia-compliant companies finds robust evidence that sharia-compliant companies have significantly higher earnings quality compared to other firms. The results also provide that sharia-compliant companies supply a higher quality of reported earnings to attract foreign investment, have greater demand for high-quality financial reporting because of their sharia status and are subject to greater scrutiny by regulators and institutional investors. Therefore sharia-compliant companies must show a good reputation in promoting Islamic capital market.

Hence, study that focus on the volatility of the share price found varies findings. For example, Sankaran et al., (2012) investigate the extreme returns in a variety of financial markets found the correlation positive extreme returns within overlapping clusters significantly increases with volatility between Dow Jones Industrial Average and S\&P 500. Then Kongsilp and Mateus, (2017) investigate the role of volatility risk on stock return found a clear and robust empirical evidence. Fowowe (2017) examine the return and volatility spillovers between oil and the stock markets of Nigeria and South Africa. The results for volatility spillovers show independence of volatilities between Nigeria stock markets and oil markets, while weak bi-directional spillovers were found between South African equity volatilities and oil volatilities.

Lee (2009) examines the housing price volatility for eight capital cities in Australia. The volatility clustering effects were found in many Australian capital cities. Coskun, et al., (2016) analyze volatility properties of the house price returns of Turkey, Istanbul, Ankara and Izmir. Empirical findings suggest several points. The important finding are; the city/country-level house price return volatility series display volatility clustering pattern and therefore volatilities in house price returns are time varying; house price return volatilities differ across geographic areas, volatility series may show some co-movement pattern. Thus, volatility is important to investigate in order to monitor the performance of share prices.

\section{RESEARCH METHODOLOGY}

This study analyzed the stock prices of 19 shariacompliant companies to detect volatility rate. Therefore, this study implemented mathematical calculation to find return rate including volatility rate. The data distribution evaluation for both variables is performed using ShapiroWilk normality test.

\subsection{Data selection and return calculation}

This study collected daily stock prices from Thomson Reuters Datastream. Table 1 shows selected 19 shariacompliant companies listed on Malaysia Stock Exchange. These companies are selected among 30 companies that composing Kuala Lumpur Composite Index (KLCI).

Table.1: List of companies

\begin{tabular}{|c|l|}
\hline No. & Company Name \\
\hline 1 & Axiata Group Berhad \\
\hline 2 & Dialog Group Berhad \\
\hline 3 & DiGi.Com Berhad \\
\hline 4 & Hartalega Holdings Berhad \\
\hline 5 & IHH Healthcare Berhad \\
\hline 6 & IOI Corporation Berhad \\
\hline 7 & Kuala Lumpur Kepong Berhad \\
\hline 8 & Maxis Berhad \\
\hline 9 & MISC Behad \\
\hline 10 & Nestle (Malaysia) Berhad \\
\hline 11 & Petronas Chemicals Group Berhad \\
\hline 12 & Petronas Dagangan Bhd \\
\hline 13 & Petronas Gas Berhad \\
\hline 14 & PPB Group Berhad \\
\hline 15 & Press Metal Aluminium Holdings Berhad \\
\hline 16 & Sime Darby Berhad \\
\hline 17 & Sime Darby Plantation Berhad \\
\hline 18 & Tenaga Nasional Berhad \\
\hline 19 & Top Glove Corporation Berhad \\
\hline
\end{tabular}

Then, the stock prices are averaged to find monthly stock price. Next, this study calculated the return rate using using Equation (1).

$\operatorname{Re}_{i, t}=\left(\frac{P_{t}-P_{t-1}}{P_{t-1}}\right) \times 100 \%$

In Equation (1), the parameters are described as below:

$\operatorname{Re}_{i, t}$ : Return rate for company $i$ at monthly observation period $t$,

$P_{t}$ : Stock prices of company $i$ at monthly observation period $t$, and

$P_{t-1}$ : Stock prices of company $i$ at monthly observation period $t-1$.

Next, the volatility rate is measured using standard deviation of data distribution. Therefore, the volatility is described using Equation (2). 
$\sigma_{i}=\sqrt{\frac{\left(r_{i, t}-\bar{r}_{i}\right)}{n-1}}$

In Equation (2), the parameters are described as follows:

$\sigma_{i}$ : Volatility rate for company $i$,

$r_{i, t}$ : Observed variable for return of company $i$ at monthly period $t$,

$\bar{r}_{i}$ : Mean value of return for company $i$, and

$n:$ Number of observation.

\subsection{Shapiro-Wilk normality test}

An assessment of the normality of data is a prerequisite for many statistical tests because normal data is an underlying assumption in parametric testing. In this study, Shapiro-Wilk normality test is selected for data distribution analysis. The Shapiro-Wilk normality test is more appropriate for small sample sizes (<50 samples), but can also handle sample sizes as large as 2000.

Suppose that a random variable $\mathrm{X}$ is observed and this study interested in testing the hypothesis of normality of data distribution. The null-hypothesis of Shapiro-Wilk test is that the population is normally distributed.

$$
H_{0}: X \approx N\left(\mu, \sigma^{2}\right)
$$

Shapiro-Wilk normality testing is represented by Wstatistics. The $W$-test statistics is indicated by Equation (3).

$W=\frac{\left(\sum_{i=1}^{n} a_{i} X_{(i)}\right)^{2}}{\sum_{i=1}^{n}\left(X_{i}-\bar{X}\right)^{2}}$

where $X_{(1)} \leq X_{(2)} \leq \ldots \leq X_{(n)}$ are the ordered values of a sample of $X_{1}, X_{2}, \ldots, X_{n}$. A lower tail of $\mathrm{W}$ indicates non-normality. The tabulated coefficients $a_{i}$ are described as Equation (4).

$$
\left(a_{1}, a_{2}, \ldots, a_{n}\right)=\frac{m^{\mathrm{T}} V^{-1}}{C}
$$

In Equation (4), the parameters are described as follows: $C$ : Vector norm is a function that assigns a strictly positive length or size to each vector in a vector space,

$$
C=\left\|V^{-1} m\right\|=\sqrt{\left(m^{\mathrm{T}} V^{-1} V^{-1} m\right)}
$$

$m$ : Vector $m$ is made of the expected values of the order statistics of independent and identically distributed random variables sampled from the standard normal distribution.

$$
m=\left(m_{1}, m_{2}, \ldots, m_{n}\right)^{\mathrm{T}}
$$

$V$ : Covariance matrix for normal order statistics.

Next, assume the expected value of mean $\mu$ is known as $\mu_{0}$.Therefore, the null hypothesis of Shapiro-Wilk normality test can be expressed as below.

$$
H_{0}: X \approx N\left(\mu_{0}, \sigma^{2}\right)
$$

Next, the W-test statistics can be re-arranged as below:

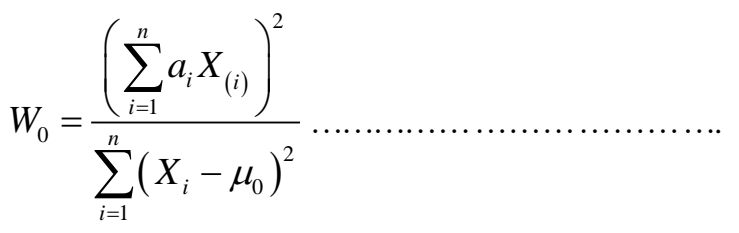

The null hypothesis is rejected at condition of $W_{0}<W_{0}(\alpha, n)$. The parameter $W_{0}(\alpha, n)$ is critical value at significant level $\alpha$.

The statistics $W_{0}$ has identical properties to $W$ statistics. The parameter $W_{0}$ is scale invariant and maximum value of $W_{0}$ is set to one. Meanwhile, the minimum value of $W$ is decided with value in below equation.

$\varepsilon=\frac{n a_{1}^{2}}{n-1}$

\section{RESULT AND DISCUSSION}

The objective of this study is to evaluate level of volatility among sharia-compliant companies listed on Malaysia Stock Exchange. The selected 19 companies are listed as companies in FTSE Bursa Malaysia KLCI. This study evaluated the data distribution for return rate and volatility rate to examine financial environment in Malaysia Stock Exchange.

4.1 Data analysis for return rate

This section describes data distribution for return rate of 19 companies of sharia-compliant companies that selected among 30 companies for Kuala Lumpur Composite Index (KLCI). Figure 1 shows the return rate distribution for 19 companies. The maximum value of average monthly return is $3.16 \%$ for Nestle (Malaysia) Berhad (Company No. is 10). Meanwhile, the minimum value of average monthly return is $-2.01 \%$ for Axiata Group Berhad (Company No. is 1).

Next, this study performed normality analysis for data distribution of return rate. Figure 2 indicates data distribution of average monthly return rate using normal 
Q-Q (quantile-quantile) plot. Figure 2 concluded the distribution of average return rate is follow normal distribution because all of data is close to normal distribution line (red line). The average value for return is $0.442 \%$ and standard deviation is $1.285 \%$.

After that, the graphical finding is validated using statistical test of normal distribution. This study selected Shapiro-Wilk normality for data distribution analysis. This statistical test is selected because number of observation is less than 2000. Table 1 shows ShapiroWilk normality test for return rate. Table 1 indicates the probability value (p-value) is 0.497 that is larger than 0.05 . Therefore, data distribution of return rate is follows normal distribution.

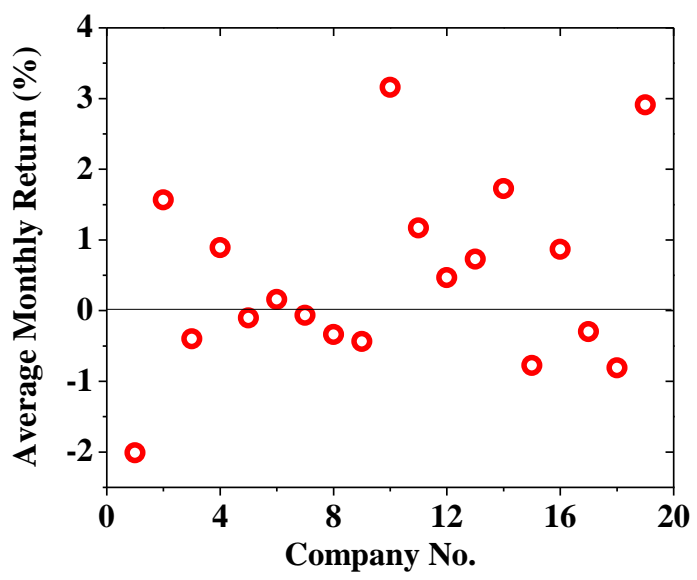

Fig. 1: Return rate distribution for company

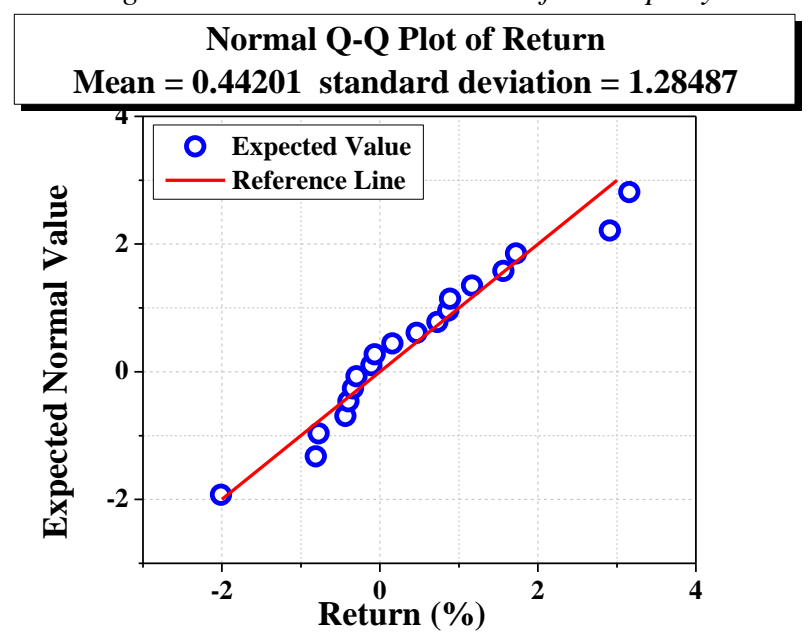

Fig. 2: Normal $Q-Q$ plot for return rate

Table.1: Normality test for return rate

\begin{tabular}{|c|c|c|}
\hline \multicolumn{3}{|c|}{ Shapiro-Wilk normality test } \\
\hline Statistics & $\begin{array}{c}\text { Degree of } \\
\text { freedom, df }\end{array}$ & $\begin{array}{c}\text { Probability value } \\
\text { (p-value) }\end{array}$ \\
\hline 0.956 & 19 & 0.497 \\
\hline
\end{tabular}

4.2 Data analysis for volatility rate

This study analyzed rate of volatility for 19 companies listed in Malaysia Stock Exchange that selected in 30 www.ijaems.com companies of Kuala Lumpur Composite Index (KLCI). Figure 3 shows the volatility rate distribution for 19 companies. The maximum value of volatility rate is 9.00 $\%$ for Top Glove Corporation Berhad (Company No. is 19). Meanwhile, the minimum value of volatility rate is $1.47 \%$ for Kuala Lumpur Kepong Berhad (Company No. is 7)

Next, this study performed normality analysis for data distribution of return rate. Figure 4 indicates data distribution of volatility rate using normal Q-Q (quantilequantile) plot. Figure 4 concluded the distribution of volatility rate is follow normal distribution because all of data is close to normal distribution line (red line). The average value for volatility is $4.85 \%$ and standard deviation is $2.23 \%$.

After that, the graphical finding is validated using statistical test of normal distribution. This study selected Shapiro-Wilk normality for data distribution analysis. This statistical test is selected because number of observation is less than 2000. Table 2 shows ShapiroWilk normality test for volatility rate. Table 2 indicates the probability value (p-value) is 0.562 that is larger than 0.05 . Therefore, data distribution of return rate is follows normal distribution.

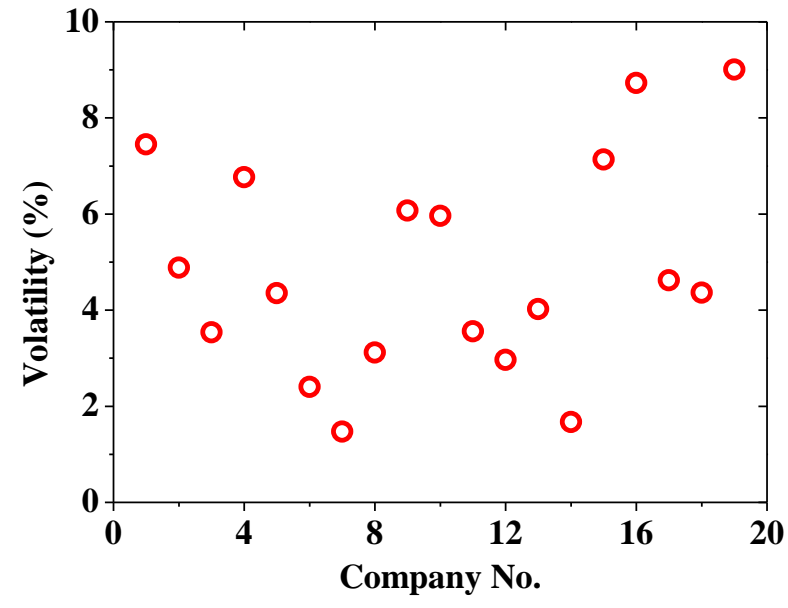

Fig. 3: Volatility rate for company

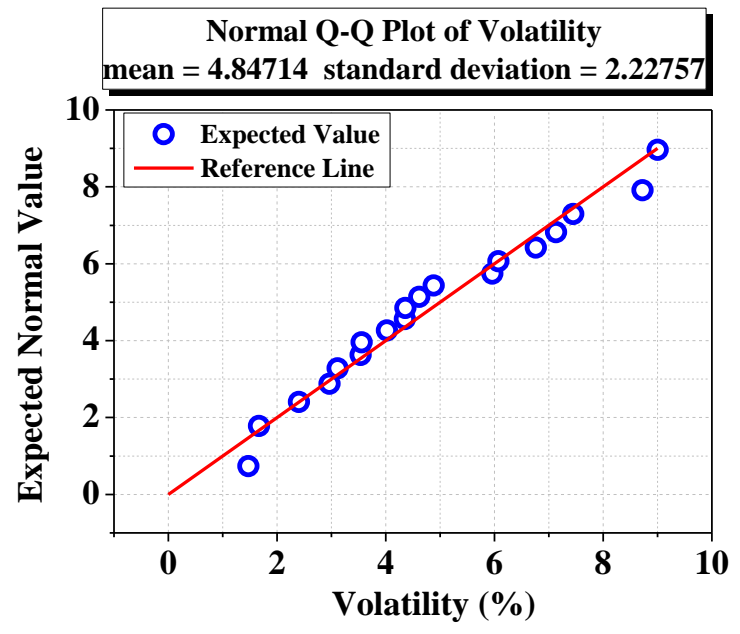

Fig. 4: Normal $Q-Q$ plot for volatility rate 
Table.2: Normality test for volatility rate

\begin{tabular}{|c|c|c|}
\hline \multicolumn{3}{|c|}{ Shapiro-Wilk normality test } \\
\hline Statistics & $\begin{array}{c}\text { Degree of } \\
\text { freedom, df }\end{array}$ & $\begin{array}{c}\text { Probability value } \\
\text { (p-value) }\end{array}$ \\
\hline 0.959 & 19 & 0.562 \\
\hline
\end{tabular}

\section{CONCLUSION}

Main purpose of this study is to evaluate the volatility rate for companies listed on Malaysia Stock Exchange. The companies selected in this analysis are 19 companies that sharia-compliant. The selected companies are categorized in 30 companies that determine Kuala Lumpur Composite Index (KLCI).

Main findings of this study are:

(a) The distribution of average return rate is follow normal distribution because all of data is close to normal distribution line. The average value for return is $0.442 \%$ and standard deviation is $1.285 \%$.

(b) Shapiro-Wilk normality test for return rate indicates the probability value ( $\mathrm{p}$-value) is 0.497 that is larger than 0.05 . Therefore, data distribution of return rate is follows normal distribution.

(c) The maximum value of average monthly return is $3.16 \%$ for Nestle (Malaysia) Berhad. Meanwhile, the minimum value of average monthly return is $-2.01 \%$ for Axiata Group Berhad.

(d) The distribution of volatility rate is follow normal distribution because all of data is close to normal distribution line. The average value for volatility is $4.85 \%$ and standard deviation is $2.23 \%$.

(e) Shapiro-Wilk normality test for volatility rate. Table 2 indicates the probability value ( $p$-value) is 0.562 that is larger than 0.05 . Therefore, data distribution of return rate is follows normal distribution.

(f) The maximum value of volatility rate is $9.00 \%$ for Top Glove Corporation Berhad. Meanwhile, the minimum value of volatility rate is $1.47 \%$ for Kuala Lumpur Kepong Berhad.

The significant of these findings is it will help investors to understand the behavior of stock price in Malaysia Stock Exchange particularly sharia-compliant companies in Kuala Lumpur Composite Index. In addition, the findings of this study will help investors to develop investment portfolio that can maximize return and reducing loss.

\section{REFERENCES}

[1] Abdul Rahim, R. and Yong, O. (2010). Initial returns of Malaysian IPOs and Sharia-compliant status. Journal of Islamic Accounting and Business Research, 1(1), 60-74.

[2] Abu Bakar, N. and Rosbi, S. (2017a). Data modeling diagnostics for share price performance of Islamic
Bank in Malaysia using Computational Islamic Finance approach. International Journal of Advanced Engineering Research and Science, 4 (7), 174-179.

[3] Abu Bakar, N and Rosbi, S. (2017b). Dynamic Forecasting method for Shariah-compliant Share Price of Healthcare sector in Malaysian Stock Exchange. International Journal of Advanced Engineering, Management and Science, 3 (8), 855863.

[4] Abu Bakar, N. and Rosbi, S. (2018a). Evaluation of Risk Reduction for Portfolio in Islamic Investment Using Modern Portfolio Theory. International Journal of Advanced Engineering Research and Science, 5 (11), 27-34.

[5] Abu Bakar, N., Rosbi, S. and Uzaki, K. (2018b). Evaluating Forecasting Method Using Autoregressive Integrated Moving Average (ARIMA) Approach for Shariah Compliant Oil and Gas Sector in Malaysia. Journal of Mathematics and Computing Science, 1 (1), 19-33.

[6] Ahmed Haji, A., Mohd Ghazali, N.A. (2013). The quality and determinants of voluntary disclosures in annual reports of Shari'ah compliant companies in Malaysia. Humanomics, 29(1), 24-42.

[7] Che Azmi, A., Ab Aziz, N., Non, N. and Muhamad, R. (2016). Sharia disclosures: An exploratory study from the perspective of Sharia-compliant companies and profes sionalusers. Journal of Islamic Accounting and Business Research, 7(3), 237.

[8] Che Azmi, A., Ab Aziz, N., Non, N. and Muhamad, R. (2016). Sharia disclosures: An exploratory study from the perspective of Sharia-compliant companies and professionalusers. Journal of Islamic Accounting and Business Research, 7(3), 237-252.

[9] Che Azmi, A., Ab Aziz, N., Non, N. and Muhamad, R. (2016). Sharia disclosures: An exploratory study from the perspective of Sharia-compliant companies and profes sional users. Journal of Islamic Accounting and Business Research, 7 (3), 237-252.

[10] Coskun, Y. and Ertugrul, H.M. (2016). House price return volatility patterns in Turkey, Istanbul, Ankara and Izmir. Journal of European Real Estate Research, 9 (1), 26-51.

[11] Fowowe, B. (2017). Return and volatility spillovers between oil and stock markets in South Africa and Nigeria. African Journal of Economic and Management Studies, 8(4), 484-497.

[12] Hamza, H. (2013). Sharia governance in Islamic banks: effectiveness and supervision model. International Journal of Islamic and Middle Eastern Finance and Management, 6 (3), 226-237.

[13] Kongsilp,W. and Mateus, C. (2017). Volatility risk and stock return predictability on global financial 
crises. China Finance Review International, 7 (1), 33-66.

[14] Lee, C.L. (2009). Housing price volatility and its determinants. International Journal of Housing Markets and Analysis, 2(3), 293-308.

[15] Lusyana, D. and Sherif, M. (2017). Shariahcompliant investments and stock returns: evidence from the Indonesian stock market. Journal of Islamic Accounting and Business Research, 8 (2), 143-160.

[16] Ousama, A.A. and Fatima, A.H. (2010). Voluntary disclosure by Shariah approved companies: an exploratory study. Journal of Financial Reporting and Accounting, 8 (1), 35-49.

[17] Sankaran, H., Nguyen, A. and Harikumar, J. (2012). Extreme return correlation and volatility: a two-threshold approach. American Journal of Business, 27(2), 154-173.

[18] Securities Commission of Malaysia, (2018). Available at: https://www.sc.com.my/api/documentms/download.a shx?id=f325b375-67e9-49c3-a45d-4864c8a6be7f

[19] Shaik, M. and Maheswaran S., (2018). Evidence of excess volatility based on a new robust volatility ratio. Journal of Economic Studies, 45 (4), 855-875.

[20] Ullah, S., Jamali, D. and Harwood, I.A. (2014). Socially responsible investment: insights from Shari'a departments in Islamic financial institutions. Business Ethics: A European Review, 23 (2), 218233.

[21] Wan Ismail, W.A. Kamarudin, K.A. and Sarman, S.R. (2015). The quality of earnings in Shariahcompliant companies: evidence from Malaysia. Journal of Islamic Accounting and Business Research, 6 (1),19-41. 